\title{
City and Society in the Low Countries, 1100-1600
}

\section{Edited by}

Bruno Blondé

University of Antwerp

Marc Boone

Ghent University

Anne-Laure Van Bruaene

Ghent University 


\section{CAMBRIDGE UNIVERSITY PRESS}

University Printing House, Cambridge CB2 8BS, Unițed Kingdom One Liberty Plaza, 20th Floor, New York, NY 10006, USA 477 Williamstown Road, Port Melbourne, VIC 3207, Australia

314-321, 3rd Floor, Plot 3, Splendor Forum, Jasola District Centre, New Delhi - 110025, India

79 Anson Road, \#06-04/06, Singapore 079906

Cambridge University Press is part of the University of Cambridge.

It furthers the University's mission by disseminating knowledge in the pursuit of education, learning and research at the highest international levels of excellence.

www.cambridge.org

Information on this title: www.cambridge.org/9781108474689 DOI: $10.1017 / 9781108645454$

Originally published in Dutch by Academia Press 2016

as Gouden eeuwen: Stad en samenleving in de Lage Landen, 1100-1600

This publication is in copyright. Subject to statutory exception and to the provisions of relevant collective licensing agreements, no reproduction of any part may take place without the written permission of Cambridge University Press.

First published in English by Cambridge University Press 2018 as City and Society in the Low Countries, 1100-1600

English translation (c) Cambridge University Press 2018

Printed in the United Kingdom by TJ International Ltd. Padstow Cornwall A catalogue record for this publication is available from the British Library. ISBN 978-1-108-47468-9 Hardback

Cambridge University Press has no responsibility for the persistence or accuracy of URLs for external or third-party internet websites referred to in this publication and does not guarantee that any content on such websites is, or will remain, accurate or appropriate. 


\section{Contents}

List of Figures

List of Contributors

page xi

Acknowledgements

1 City and Society in the Low Countries: Urbanisation and Urban Historiography BRUNO BLONDÉ, MARC BOONE AND ANNE-LAURE VAN BRUAENE

2 Economic Vitality: Urbanisation, Regional Complementarity and European Interaction WIM BLOCKMANS, BERT DE MUNCK AND PETER STABEL

3 Living Together in the City: Social Relationships Between Norm and Practice BRUNO BLONDÉ, FREDERIK BUYLAERT, JAN DUMOLYN, JORD HANUS AND PETER STABEL

4 'The Common Good': Governance, Discipline and Political Culture MARC BOONE AND JELLE HAEMERS

5 Civic Religion: Community, Identity and Religious Transformation GUIDO MARNEF AND ANNE-LAURE VAN BRUAENE CLAIRE BILLEN AND CHLOÉ DELIGNE

7 At Home in the City: The Dynamics of Material Culture INNEKE BAATSEN, BRUNO BLONDÉ, JULIE DE GROOT AND ISIS STURTEWAGEN 
8 Education and Knowledge: Theory and Practice in an Urban Context

BERT DE MUNCK AND HILDE DE RIDDER-SYMOENS

9 Epilogue: The Legacy of the Medieval City in the Low Countries

BRUNO BLONDÉ, MARC BOONE AND

ANNE-LAURE VAN BRUAENE

Select Bibliography

Index 